\title{
THE DIFFUSION OF FINANCIAL INNOVATIONS:
}

AN EXAMINATION OF THE ADOPTION OF SMALL BUSINESS CREDIT SCORING

BY LARGE BANKING ORGANIZATIONS

\author{
Jalal Akhavein \\ Wharton Financial Institutions Center \\ University of Pennsylvania \\ 3620 Locust Walk \\ Philadelphia, PA 19104 \\ Tel: 215-573-8074 \\ Fax: 215-573-6073 \\ e-mail: akhavein@wharton.upenn.edu \\ W. Scott Frame \\ Research Department \\ Federal Reserve Bank of Atlanta \\ 104 Marietta Street NW \\ Atlanta GA 30303 \\ Tel: 404-521-8783 \\ Fax: 404-521-8810 \\ e-mail: scott.frame@atl.frb.org \\ Lawrence J. White* \\ Stern School of Business \\ New York University \\ 44 West $4^{\text {th }}$ Street \\ New York, NY 10012-1126 \\ Tel: 212-998-0880 \\ Fax: 212-995-4218 \\ e-mail: lwhite@stern.nyu.edu \\ * Please address correspondence to this author
}

March, 2001

Keywords: Credit Scoring; Small Business Lending; Financial Innovation; Technology

Diffusion

JEL Classification Numbers: G2, O3, L2

The authors thank William Greene and seminar participants at the 2000 Atlantic Economic Association meetings for helpful comments. The views expressed in this paper are those of the authors and not those of the Federal Reserve Bank of Atlanta or the Federal Reserve System. 


\begin{abstract}
$\underline{\text { Abstract }}$
Financial innovation has been described as the "life blood of efficient and responsive capital markets." Yet, there have been few quantitative investigations of financial innovation and the diffusion of these new technologies. Of the latter, there have been only

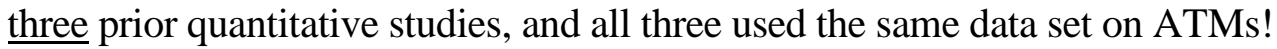

This paper makes a significant contribution to the financial innovation literature by examining the diffusion of a recent important innovation of the 1990s: banks' use of credit scoring for small business lending. We examine the responses of 95 large banking organizations to a survey that asked whether they had adopted credit scoring for small business lending as of June 1997 (56 had done so) and, if they had adopted it, when they had done so. We estimate hazard and tobit models to explain the diffusion pattern of small business credit scoring models. Explanatory variables include several market, firm, and managerial factors of the banking organizations' under study.

The hazard model indicates that larger banking organizations innovated earlier, as did those located in the New York Federal Reserve district; both results are consistent with our expectations. The tobit model confirms these results and also finds that organizations with fewer separately chartered banks but more branches innovated earlier, which is consistent with theories stressing the importance of bank organizational form on lending style. Though the managerial variables' signs are consistent with our expectations, none yields significant results.
\end{abstract}


"One of the bedrocks of our financial system is financial innovation, the life blood of efficient and responsive capital markets." Van Horne (1985)

\section{Introduction}

It is widely recognized that innovation plays a crucial role in improving productivity. Equally important, however, is the rate at which innovations diffuse through an economy. Faster diffusion of innovations means a more immediate impact, and thus a higher social return on the initial investment.

There is general recognition of the particular importance of financial innovation (e.g., Silber 1975; Van Horne 1985; Miller 1986, 1992; Faulhaber and Baumol 1988; Campbell 1988, ch. 16; Siegel 1990; Finnerty 1992; and Merton 1992). However, the number of quantitative studies of financial innovation are relatively few and relatively recent (e.g., Garbade and Silber 1978; Hannan and McDowell 1984, 1987; Saloner and Shephard 1995; Lea 1996; Lerner 2000; Furst, et al. 2000; and Frame, et al. 2001)!

Further, we have been able to find only three quantitative studies that examine the diffusion process for financial innovations (Hannan and McDowell 1984, 1987; Saloner and Shepherd 1995), all using the same data on the introduction of automated teller machines.

This paper will contribute to the empirical literature on the diffusion of financial innovations. Specifically, using a unique survey data set, we examine the introduction of credit scoring techniques for small business loan applications during the middle 1990s. This

1 This is in comparison with the much larger and much older set of quantitative studies that encompass innovation in manufacturing and agriculture. See Cohen and Levin (1989) for a review.

2 Again, this is in contrast with a larger, older, and more varied set of diffusion studies that exist for manufacturing and agriculture. See, for example, Griliches (1957); Hagerstrand (1967); Mansfield (1968a, 1968b); Mansfield et al. (1977); Oster (1982); Thwaites (1982); Rees et al. (1984); Rose and Joskow (1990); and Baptista (2000). 
survey yielded information for 99 large banking organizations, including whether they had adopted credit scoring for small business lending by January 1998 and (if they had adopted) when they first did so. We then relate this information to a number of market, firm, and managerial factors in order to uncover the important characteristics driving technological adoption decisions by large banking organizations. This is done by estimating a parametric hazard function with time-varying covariates. ${ }^{3}$ The benefit of using this approach is that we can uncover the institutional factors that influence both the probability of and the rate of small business credit scoring adoption. Allowing these factors to evolve through time (via time-varying covariates) further enriches the model specification. We also employ tobit analysis as an alternative means of capturing the relationship between the date of a bank's adoption of credit scoring and the potential explanatory variables for its decision.

Our paper proceeds as follows. Section II provides background information about small business credit scoring. Section III outlines our variables of interest. Section IV discusses the data. Section V presents our statistical tests and results. Conclusions are provided in Section VI.

\section{Credit Scoring}

Credit scoring is the process of assigning a single quantitative measure, or score, to a potential borrower representing an estimate of the borrower's future loan performance (Feldman, 1997). While credit scores have been used for some time in the underwriting of consumer loans, this technology has only recently -- beginning in the 1990s -- been applied

\footnotetext{
${ }^{3}$ The estimation of such hazard functions falls under the rubric of duration or survivor analysis. See Kalbfleisch and Prentice (1980), Cox and Oakes (1984), and Kiefer (1988) for an introduction to duration analysis.
} 
to commercial credits. This is because commercial loans were thought to be too heterogeneous and documentation was not sufficiently standardized either within or across institutions (Rutherford 1994/1995). However, credit analysts ultimately determined that the personal credit history of small business owners is highly predictive of the loan repayment prospects of their businesses, especially for loans under $\$ 100,000 .^{4}$ Thus, personal information is obtained from a credit bureau and then augmented with basic business-specific data, so as to predict repayment. Eisenbeis (1996) presents an excellent overview of the history and application of credit scoring techniques to small business loan portfolios.

According to Feldman (1997), credit scoring will alter small business lending in three areas: (1) the interaction between borrowers and lenders; (2) loan pricing; and (3) credit availability. First, credit scoring allows lenders to underwrite and monitor loans without actually meeting the borrower. This development is in stark contrast to the perceived importance of a local bank-borrower relationship (Petersen and Rajan 1994; Berger and Udell 1995; and Cole 1998). In fact, because of scoring systems, borrowers can obtain unsecured credit from distant lenders through direct marketing channels. Second, the price of small business loans should decline -- especially for high credit quality borrowers that will no longer have to bear the cost of extensive underwriting. Also, increased competition -- resulting from small businesses having access to more lenders -- should further lower borrowing costs. ${ }^{6}$ Third, credit scoring should increase credit availability for

\footnotetext{
${ }^{4}$ Mester (1997) cites the use of information such as the applicant's monthly income, outstanding debt, financial assets, employment tenure, home ownership, and previous loan defaults or delinquencies.

${ }^{5}$ More lenders can compete for an individual borrower's loan because distance is less of a barrier and because the scoring technology may allow lenders that are not specialists at
} 
small businesses. Better information about the repayment prospects of a small business applicant makes it more likely that a lender will price the loan based on expected risk, rather than denying the loan out of fear of charging too little. Moreover, the widespread use of credit scoring should increase future prospects for asset securitization by encouraging consistent underwriting standards.

Empirical evidence concerning Feldman's predictions has thus been far limited to the effect of credit scoring on small business credit availability. Frame et al. (2001) estimate that the use of credit scoring increases the portfolio share of small business loans by 8.4 percent for their sample of large banking organizations.

This paper examines a related, but new and different issue: what factors influence the probability and timing (i.e., the diffusion) of the adoption of this new technology by its "first movers": large banking organizations. To that end, the next section discusses a number of variables that we believe may affect the conditional probability of adopting small business credit scoring models.

\section{Variables of Interest}

We believe that a number of market, firm, and managerial factors may have influenced the diffusion of credit scoring technology for small business loans. Most importantly, the rate of diffusion should be related to the expected benefits (profitability) of adopting the new technology. Indeed, various theoretical models of this exist (Davies, 1979; Reinganum, 1981a,b; Fudenberg and Tirole, 1985; and Karshenas and Stoneman, 1993). However, in the spirit of agency theory, we also believe that variations in the risk

borrower evaluation to enter the lending business. 
preferences and ability (foresight) of firm managers could also influence adoption decisions. We discuss each of the covariates included in our analysis below.

\section{A. Market Variables}

The relative competitiveness of the marketplace may influence technological adoption decisions. However, two competing theories exist. On the one hand, Schumpeter (1950) contends that large firms with market power are most likely to advance industrial technology because of their superior access to capital, the ability to pool risks, and economies of scale. On the other hand, Scherer (1984) suggests that small firms are relatively more likely to innovate than are large firms, because of standard competitive motives. Generally, as an empirical matter, Cohen and Levin (1989) report that if a relationship between market concentration and innovation exists, it is "fragile" and likely to be economically unimportant. Nevertheless, in the area of financial services innovation, Hannan and McDowell (1984) provide empirical evidence -- based on the adoption of automated teller machines by banks - that is consistent with Schumpeter's theory.

Accordingly, to account for the possible relationship between market concentration and financial innovation, we include an average Herfindahl-Hirschman Index (HHI) across all the local geographic markets in which the subsidiary banks operate weighted by their total assets in each market.

There is considerable research suggesting that technological adoption varies geographically (Hagerstrand, 1967; Thwaites, 1982; and Rees et al. 1984). Baptista (2000) suggests that these regional differences in diffusion rates result from the geographical

\footnotetext{
${ }^{6}$ Elliehausen and Wolken (1990) provide empirical support for the notion that small business lending markets tend to be local.
} 
clustering of innovators. Similarly, we posit that the geographic distribution of individuals qualified to develop and maintain sophisticated econometric credit scoring models may be

concentrated, specifically in New York and San Francisco. This conjecture is based on the tremendous demand by Wall Street firms for so-called "quants" and the fact that the largest vendor of credit scoring models (Fair Issac \& Company) is based in the San Francisco area. To account for this, we include dummy variables indicating whether the banking organization is located in the New York (NEWYORK) or San Francisco (SANFRAN) Federal Reserve districts.

\section{B. Firm Variables}

Studies have found that larger firms are likely to adopt new technologies before smaller firms (Mansfield, 1968a, 1968b, 1977; Hannan and McDowell, 1984; Rose and Joskow, 1990). This is likely due to the fact that the cost of a new technology can be spread across a larger number of units of output. To account for this, we include the natural logarithm of total domestic banking assets (LNASSETS).

We believe that banking organizations that are more focused on small business lending are more apt to adopt credit scoring. Because credit scoring serves objectively to measure and rank the riskiness of borrowers, financial institutions are better able to manage credit risk and price loans accordingly. Thus, for those institutions especially dependent on earnings from small business lending, credit scoring should be more valuable. As a result we include the ratio of small loans (under $\$ 100,000$ ) to businesses to total domestic banking assets (SBLRATIO). 
The underlying structure of the banking organization may also influence the technology adoption decision. For this reason, we include both the number of subsidiary banks (NBANKS) and the number of branches (BRANCHES) in our model. A larger number of subsidiary banks may indicate a decentralized organizational structure that emphasizes more localized control over lending decisions. We would expect that these types of banking organizations are less likely to engage in credit scoring. On the other hand, we see banking organizations with expansive branch networks as more likely to use an automated approach to underwriting loans.

The profitability of an institution may influence its propensity to adopt new technologies. Hannan and McDowell (1984) suggest that this might stem from a liquidity constraint; less profitable firms are less able to invest in new technologies ${ }^{7}$ For this reason, we include return on equity (ROE), or net income as a percent of total equity capital, as a measure of profitability.

Identifying organizational willingness to implement new programs or technologies is difficult. While this may come from chief executives (see below), it may also be related to a firm's corporate culture. For example, Furst, et al. (2000) find that the probability of federally chartered commercial banks to adopt internet banking is positively related to their reliance on non-interest income. That is, "fee income" may act as a proxy for the

\footnotetext{
7 This was one of Schumpeter's (1950) arguments in favor of monopoly (with its larger profit flow) as a superior market structure for encouraging innovation. In the language of more modern economics, the asymmetric information problems surrounding a firm's attracting "outside" finance for an investment are even greater when the investment involves uncertain new technologies that may have little liquidation value. Thus a firm with a greater capability for internal finance (from greater profits) will have an advantage with respect to investing in new technologies.
} 
aggressiveness of the bank's business strategy. Accordingly, we include the ratio of noninterest income to net operating revenue (NIINCOME).

\section{CEO Variables}

Lastly, personal characteristics of each banking organization's chief executive officer (CEO) may influence the adoption decision. This focus on management has previously been explored in the technology diffusion literature, primarily by Mansfield (1968a, 1968b, 1977). The two CEO variables we have selected are tenure and education. ${ }^{8}$ First, the length of time that an executive has been with an organization (CEOTEN) may influence decisionmaking in opposing ways. On one hand, the longer a CEO has been with a firm, the more he/she knows about its labor resources and how to mobilize them. On the other hand, new managers may be more likely to "shake-up" an organization and try new approaches especially in formerly protected industries like banking. Second, we posit that executives with additional education beyond their college degrees will be more inclined to adopt new technologies. The dummy variable ADVDEG accounts for this by taking a value of one for CEOs with graduate degrees.

\section{Data}

The data used in this study come from three sources. First, we have data recording the month and year that a sample of large banking organizations first used small business credit scoring. This information was obtained from a survey of the 200 largest U.S. banking

\footnotetext{
${ }^{8}$ In previous efforts, we had also included CEO age in our analysis. Because it was generally found to be unimportant (and correlated with CEO tenure), we have dropped it here.
} 
organizations (as of June 1997) conducted by the Federal Reserve Bank of Atlanta in January 1998. Ninety-nine institutions responded to the survey in which (among other things) respondents were asked whether their institution credit scored small business loans and, if so, when it was first implemented. See Frame et al. (2001) for a complete discussion of the survey questions and results.

Second, we use several items reported on the commercial bank Call Reports (and aggregated to the holding company level). This information was obtained from the Wharton Financial Institutions Center (which, in turn, obtained the data from the Federal Reserve Board). Since information about banks' small business lending activities is only collected on the mid-year Call Report (and only since 1993), this is how we organize our analysis. As a result, we focus on annual, mid-year observations for each large banking organization between 1993-1997.

Lastly, we collected data on the personal characteristics of the chief executive officers (CEOs) of each large banking organization that responded to our survey. Specifically, information on CEO tenure and education was obtained primarily from the

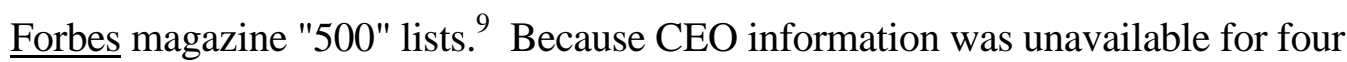
institutions (all foreign-owned), our analysis ultimately focuses on a total of 95 large banking organizations.

Table 1 provides the descriptive statistics for our sample, as of June 1997. Of the 95 large banking organizations in our sample, 55 (58 percent) had adopted credit scoring for small business lending by June 1997. Of those that did adopt, nine had adopted before

\footnotetext{
${ }^{9}$ This biographical information can be found on the Forbes website (www.forbes.com). For information on CEOs who were not in those lists, we turned to various "Who's Who" directories and news stories in the American Banker.
} 
1995, while the remainder adopted during the last few years of our sample period. On average, the large banking organizations in our sample had 1.7 percent of their portfolios devoted to small business lending. These institutions were quite profitable (an average return on equity of almost 16 percent) and earned about 30 percent of their revenues from fees. These banking organizations averaged seven subsidiary banks and 367 bank branches. Almost 13 percent of the institutions were located in the San Francisco Federal Reserve district, while over seven percent were in the New York district. On average, chief executives in the sample organizations had been in their positions for over nine years, and about half (47 percent) had advanced degrees.

Table 2 provides the simple correlation matrix among the variables listed in Table 1. We have also included ADOPT, which is a dummy variable indicating whether the banking organization had adopted the innovation by June 1997, and YEARS, which is an integer equal to the number of years that the institution has used credit scoring. For example, YEARS is equal to one if the banking organization had used credit scoring for 1-12 months as of June 1997.

As can be seen, ADOPT is positively and statistically significantly related to YEARS, LNASSETS, and BRANCHES, while negatively related to SBLRATIO. YEARS is positively and statistically significantly associated with LNASSETS, BRANCHES, NEWYORK, and ADVDEG. These last four results are all consistent with the expectations discussed above.

Among the independent variables, the following interesting correlation coefficients are worth mentioning. First, SBLRATIO has significant negative associations with LNASSETS, BRANCHES, and NEW YORK and significant positive associations with 
HHI and CEOTEN. Thus, small business lending tends to be relatively less important at larger banks, banks with more branches, and banks located in the New York Federal Reserve district. Also, small business lending is more important in more concentrated markets (which tend to be smaller, less urban, and populated with smaller banks) and where the CEO has been with the bank longer (which tends to be associated with smaller banks). Second, LNASSETS has significant positive associations with BANKS, BRANCHES, ADVDEG, and NIINCOME and a significant negative association with HHI. In other words, larger banking organizations tend to have more constituent banks and branches (as expected), to have a CEO with an advanced degree, and to have higher relative non-interest income (as expected), while they tend to operate in less concentrated (larger, urban) markets.

We now turn to the detailed tests of our hypotheses.

\section{Tests and Results}

To examine the determinants of the likelihood and timing of small business credit scoring adoption we estimate two different statistical models, a hazard and a tobit. The hazard model is of primary interest because it utilizes information over the entire 1993-1997 time frame. The tobit model, which relies on cross-sectional data from 1997 for the explanatory variables, provides a supplement to the results of the hazard model. 10

The hazard model allows us to determine simultaneously the institutional factors that influence both the probability of and the rate of small business credit scoring adoption. This

\footnotetext{
${ }^{10}$ We used the 1997 data because it represents the realizations of how our sample institutions evolved over the 1993-1997 period. Using the 1993 data, by contrast, may not be as good a predictor of future activity because future business decisions are unobserved or otherwise unaccounted for.
} 
approach views the adoption of small business credit scoring as the "hazard" and therefore only includes observations during which these models are not being used by the institution. The dependent variable in this model is the natural logarithm of the number of years until adoption occurs. A detailed description of hazard, or duration, analysis is provided below.

The dependent variable in the tobit model is the number of years that the banking organization had been using credit scoring as of June 1997 (YEARS). Thus, large banking organizations that had not adopted credit scoring for their small business loan portfolios are censored and are coded with zero. The estimated coefficients in the tobit model tell us what variables influence the timing of credit scoring adoption.

Denoting $Y$ as the relevant dependent variable (and suppressing the institution and time subscripts), the following relationship can be denoted for both statistical models:

(1) $\mathrm{Y}=f$ (SBLRATIO, LNASSETS, BANKS, BRANCHES, HHI, SANFRAN, NEWYORK, ADVDEG, CEOTEN, ROE, NIINCOME).

Both models are estimated by maximum likelihood using LIMDEP, Version 7.0.

\section{A. Hazard Model}

To examine both the likelihood and rate of small business credit scoring adoption, we estimate a hazard model. Using standard duration analysis, we estimate a hazard rate at which firms adopt small business credit scoring conditional on both time and the market, firm, and CEO characteristics outlined in Section IV. To this end, we begin by providing an overview of duration analysis and then turn to the results yielded by this procedure.

\section{Overview}


The variable of interest in the analysis of duration is the length of time, $T$, that elapses from the beginning of some event until its end or until measurement is taken (Greene, 1997). In our case, we are interested in the length of time that elapses before large banking organizations adopt credit scoring for underwriting small business loans. We then estimate a hazard rate, or the probability of an adoption in each year given that the institution has not introduced credit scoring by that time.

Following Kiefer (1988), we describe a cumulative probability distribution as:

$$
\mathrm{F}(\mathrm{T})=\operatorname{Prob}(\mathrm{T} \leq \mathrm{t})
$$

or the probability that the non-negative random variable $T$ is less than some value $t$. By definition, this cumulative probability can also be described in terms of a probability density function:

$$
f(t)=d F(t) / d t=F^{\prime}(t)
$$

Alternatively, one can specify a survival function,

$$
\mathrm{S}(\mathrm{t})=1-\mathrm{F}(\mathrm{T})=\operatorname{Prob}(\mathrm{T} \geq \mathrm{t})
$$

Given these definitions (2)-(4), we can then present a hazard function or the probability that an institution will adopt small business credit scoring at time $T$, given that it has not done so by that time:

$$
\lambda(\mathrm{t})=\mathrm{f}(\mathrm{t}) / \mathrm{S}(\mathrm{t})
$$

Furthermore, by substituting (3) and (4) into (5) it can also be shown that:

$$
\lambda(\mathrm{t})=-\mathrm{d} \ln \mathrm{S}(\mathrm{t}) / \mathrm{dt} .
$$

The hazard function may also be related to explanatory variables:

$$
\lambda(\mathrm{t})=f\left(\mathrm{X}_{\mathrm{t}} \beta\right)
$$

where $X$ is a matrix of variables influencing the hazard rate and $\beta$ is a vector of regression 
coefficients. The variables in $\mathrm{X}$ may also be updated through time reflecting what the duration literature refers to as time-varying covariates.

Assuming a particular underlying probability distribution for $\lambda$ implies a likelihood function that can be maximized to generate parameter estimates for $\beta$ and any other variables dictated by the distribution of $\lambda$. However, as noted by Greene (1997), censoring is a pervasive and usually unavoidable problem in the analysis of duration data. As a result, the general form of the log-likelihood function is:

$$
L(\theta)=\sum_{i=1}^{n} d_{i} \ln f(t, \theta)+\sum_{i=1}^{n}\left(1-d_{i}\right) \ln S(t, \theta)
$$

where the indicator $d_{i}$ equals one for an uncensored observation and zero otherwise.

For our sample of 95 large U.S. banking organizations, we observe credit scoring adoption decisions annually over the 1993-1997 period. Those institutions that had not adopted credit scoring by mid-year 1997 are "right censored" and therefore have no "failure times." We estimate this model, including time-varying covariates, assuming a Weibull distribution. 11 The Weibull distribution is selected because it is consistent with the overallincreasing rate of credit scoring adoption observed during the sample period.

\section{Results}

Table 3 presents the estimation results for the parametric hazard function assuming a Weibull process for the hazard rates. ${ }^{12}$ We find that only two of our variables of interest are

\footnotetext{
${ }^{11}$ Kiefer (1988) and Greene (1997) both present the survivor, probability distribution, and hazard functions for the Weibull and other distributions.

12 Note that we must be careful in interpreting the parameters: a negative coefficient means a negative effect on duration and therefore a positive effect on adoption speed.
} 
statistically related to the rate of small business credit scoring adoption: LNASSETS and NEWYORK. Specifically, the model indicates that both variables are negatively related to the probability of not adopting small business credit scoring through the sample period. Equivalently, larger banking organizations and those headquartered in the New York Federal Reserve district tended to adopt the new technology sooner. As noted above, these findings are consistent with the presence of increasing returns to technology adoption and the geographic clustering of adopters. There is little discernable relationship between the rate of credit scoring adoption and any of our other market, firm, or CEO variables. As measured by a log-likelihood ratio (chi-square) test, the model easily rejects the null hypothesis of no relationship at a 1 percent level.

Next, we estimate a somewhat similar tobit model to supplement our results.

\section{B. Tobit Model}

Table 4 displays the results for the tobit analysis, in which YEARS is the dependent variable. Consistent with the hazard model results, we find a positive and statistically significant coefficient on LNASSETS. This indicates that, as predicted, the larger institutions adopted credit scoring before the smaller ones. Second, we find that the coefficient on NEWYORK is positive and marginally significant (at the 11 percent level). This finding is consistent with the literature on the geographic diffusion of new technologies. We also find that YEARS is negatively related to the number of subsidiary banks and positively related to the number of bank branches. ${ }^{13}$ However, the coefficient on

13 This result is consistent with results reported by Frame et al. (2001) for the probability of having adopted small business credit scoring. 
BRANCHES is only marginally significant (14 percent level). These results support the conjecture that bank organizational structure influences lending style.

One additional note about the tobit model is that the coefficient on ADVDEG is positive, but only modestly significant (at the 17 percent level). Further, going back to the simple correlation coefficients (Table 2), there was a significant positive association between YEARS and ADVDEG. We suspect that since ADVDEG is positively correlated with LNASSETS, and the latter variable is significant in the tobit regression, it is possible that the positive influence of ADVDEG has been subsumed within LNASSETS. As was true for the hazard model, a log-likelihood (chi-square) test easily allows us to reject the null hypothesis at the 1 percent level.

\section{Conclusions}

In this paper we have tested a diffusion model of technology adoption for the financial services industry. Specifically, we examine the characteristics of the early adopters of small business credit scoring using two statistical tests. Using both hazard and tobit analysis, we find that larger banking organizations and those located in the New York Federal Reserve district adopted small business credit scoring before their peers. The former finding is consistent with the presence of economies of scale for technology adoption, and the latter with theories of geography-dependent innovation diffusion. The tobit analysis also indicates that the likelihood of adopting small business credit scoring was positively related to the size of the branching network and negatively related to the number of bank charters. This is consistent with theories concerning the relationship between bank 
organizational form and lending style. Various CEO characteristics did not have significant explanatory power in our statistical tests.

Further work can surely be done to extend these analyses. For example, it would certainly be useful to know the extent to which small business credit scoring pervades the industry today. It would also be interesting to see if our findings are consistent for other financial innovations - particularly on the credit side of the banking business. Since financial innovation is "the life blood" of the financial sector, further efforts to understand the diffusion of this vital ingredient through the sector are surely warranted.

\section{References}

Baptista, Rui. "Do Innovations Diffuse Faster Within Geographical Clusters?" International Journal of Industrial Organization. Volume 18, April 2000. Pages 515-535.

Berger, Allen N. and Gregory F. Udell. "Relationship Lending and Lines of Credit in Small Firm Finance." Journal of Business. Volume 68(3), July 1995. Pages 351-381.

Berger, Allen N., Lawrence G. Goldberg, and Lawrence J. White, "The Effects of Dynamic Changes in Bank Competition on the Supply of Small Business Credit." Federal Reserve Board, January 2001 (mimeo).

Campbell, Tim. Money and Capital Markets. Glenview, IL: Scott, Foresman, 1988.

Cohen, Wesley and Richard Levin. "Empirical Studies of Innovation and Market Structure" in Handbook of Industrial Organization, Volume 2, edited by Richard Schmalensee and Robert Willig. Amsterdam: North-Holland, 1989. Chapter 18, Pages 1059-1107.

Cole, Rebel. "The Importance of Relationships to the Availability of Credit." Journal of Banking and Finance. Volume 22(6-8), August 1998. Pages 959-977.

Cox, David and David Oakes. Analysis of Survival Data. New York: Chapman \& Hall, 1985.

Davies, S. The Diffusion of Process Innovations. Cambridge: Cambridge University Press, 1979. 
Eisenbeis, Robert. "Recent Developments in the Application of Credit Scoring Techniques to the Evaluation of Commercial Loans." IMA Journal of Mathematics Applied in Business and Industry. Volume 7, 1996. Pages 271-290.

Elliehausen, Gregory and John Wolken. "Banking Markets and the Use of Financial Services by Small and Medium-Sized Businesses." Federal Reserve Bulletin. Volume 76(10), October 1990. Pages 801-817.

Faulhaber, Gerald and William Baumol. "Economists as Innovators: Practical Products of Theoretical Research." Journal of Economic Literature. Volume 26, June 1988. Pages 577600.

Feldman, Ronald. "Banks and a Big Change in Technology Called Credit Scoring." Federal Reserve Bank of Minneapolis' The Region. September 1997. Pages 19-25.

Finnerty, John "An Overview of Corporate Securities Innovation." Journal of Applied Corporate Finance. Volume 4, Winter 1992. Pages 23-39.

Frame, W. Scott, Aruna Srinivasan, and Lynn Woolsey. "The Effect of Credit Scoring on Small Business Lending," Journal of Money, Credit, and Banking. Forthcoming, 2001.

Fudenberg Drew and Jean Tirole. "Pre-Emption and Rent Equalisation in the Adoption of New Technology. Review of Economic Studies. Volume 52(3), July 1985. Pages 383-401.

Furst, Karen, William Lang, and Daniel Nolle. "Internet Banking: Developments and Prospects," Office of the Comptroller of the Currency Working Paper Number 2000-9, September, 2000.

Garbade, Kenneth and William Silber. "Technology, Communication, and the Performance of Financial Markets." Journal of Finance. Volume 33, June 1978. Pages 819-832.

Greene, William. Econometric Analysis. New York: Macmillan, 1997.

Griliches, Zvi, "Hybrid Corn: An Exploration in the Economics of Technological Change," Econometrica. Volume 25, October 1957. Pages 501-522.

Hagerstrand, T. Innovation Diffusion as a Spatial Process. Chicago: University of Chicago Press, 1967.

Hannan, Timothy and John McDowell. "The Determinants of Technology Adoption: The Case of the Banking Firm." Rand Journal of Economics. Volume 15, Autumn 1984. Pages 328-335.

Hannan, Timothy and John McDowell. "Rival Precedence and the Dynamics of Technology Adoption: An Empirical Analysis." Economica. Volume 54, May 1987. Pages 155-171. 
Kalbfleisch, John and Robert Prentice. The Statistical Analysis of Failure Time Data. New York: Wiley, 1980.

Karshenas, Massoud and Paul Stoneman. "Rank, Stock, Order, and Epidemic Effects in the Diffusion of New Process Technologies: An Empirical Model." Rand Journal of Economics. Volume 24(4), Winter 1993. Pages 503-528.

Kiefer, Nicholas. "Economic Duration Data and Hazard Functions." Journal of Economic Literature. Volume 26, June 1988. Pages 646-679.

Lea, Michael. "Innovation and the Cost of Credit: A Historical Perspective." Housing Policy Debate. Volume 7(1), 1996. Pages 147-174.

Lerner, Josh. "Where Does State Street Lead? A First Look at Finance Patents, 1971-2000." National Bureau of Economic Research Working Paper, Number 7918. September 2000.

Mansfield, Edwin. The Economics of Technological Change. New York: Norton, 1968(a).

Mansfield, Edwin. Industrial Research and Technological Innovation: Econometric Analysis. New York: Norton, 1968(b).

Mansfield, Edwin, John Rapoport, Anthony Romeo, Edmond Villani, Samuel Wagner, and Frank Husic, The Production and Application of New Industrial Technology. New York: Norton, 1977.

Merton, Robert C. "Financial Innovation and Economic Performance," Journal of Applied Corporate Finance. Volume 4, Winter 1992. Pages 12-22.

Mester, Loretta. "What's the Point of Credit Scoring?" Federal Reserve Bank of Philadelphia Business Review. September/October 1997. Pages 3-16.

Miller, Merton H. "Financial Innovation: Achievements and Prospects." Journal of Applied Corporate Finance. Volume 4, Winter 1992. Pages 4-12.

Miller, Merton H. "Financial Innovation: The Last Twenty Years and the Next," Journal of Financial and Quantitative Analysis. Volume 21, December 1986. Pages 459-471.

Oster, Sharon. "The Diffusion of Innovation among Steel Firms: The Basic Oxygen

Furnace.” Bell Journal of Economics. Volume 13, Spring 1982. Pages 45-56.

Petersen, Mitchell and Raghuram Rajan. "The Benefits of Lending Relationships: Evidence From Small Business Data." Journal of Finance. Volume 49(1), March 1994. Pages 3-37. 
Rees, John, Ronald Briggs, and Raymond Oakey. "The Adoption of New Technology in the American Machinery Industry." Regional Studies. Volume 18(6), December 1984. Pages 489-504.

Reinganum, Jennifer. "Market Structure and the Diffusion of New Technology. Bell Journal of Economics. Volume 12, Autumn 1981(a). Pages 618-624.

Reinganum, Jennifer. "On the Diffusion of New Technology: A Game Theoretic Approach." Review of Economic Studies. Volume 48, 1981(b). Pages 395-405.

Rose, Nancy and Paul Joskow. "The Diffusion of New Technologies: Evidence from the Electric Utility Industry." Rand Journal of Economics. Volume 21, Autumn 1990. Pages 354-373.

Rutherford, Reid. "Securitizing Small Business Loans: A Banker's Action Plan." Commercial Lending Review. Volume 10(1), Winter 1994/1995. Pages 62-74.

Saloner, Garth and Andrea Shepard. "Adoption of Technologies with Network Effects: An Empirical Examination of the Adoption of Automated Teller Machines." Rand Journal of Economics. Volume 26, Autumn 1995. Pages 479-501.

Schumpeter, Joseph A. Capitalism, Socialism, and Democracy, $3^{\text {rd }}$ edn. New York: Harper \& Brothers, 1950.

Siegel, Daniel. Innovation and Technology in the Markets: A Reordering of the World's Capital Market System. Chicago: Probus, 1990.

Silber, William. Financial Innovation. Lexington, MA: Heath, 1975.

Thwaites, Alfred. "Some Evidence of Regional Variations in the Diffusion of New Industrial Products and Processes within the British Manufacturing Industry." Regional Studies. Volume 16(5), October 1982. Pages 371-381.

Van Horne, James. "Of Financial Innovations and Excesses." Journal of Finance. Volume 40(3), July 1985. Pages 621-636.

Williamson, Oliver. "The Economics of Defense Contracting: Incentives and Performance" in Issues in Defense Economics, edited by Roland McKean. New York: Columbia University Press, 1967. 


\section{Table 1 \\ Sample Statistics for 95 Large U.S. Banking Organizations}

(Data as of June 30, 1997)

Number of Banking Organizations that had adopted credit scoring for small business lending by June 1997: 55

Number that adopted in 1992: 1

Number that adopted in 1993: 2

Number that adopted in 1994: 6

Number that adopted in 1995: 9

Number that adopted in 1996: 28

Number that adopted in 1997: 9

\begin{tabular}{|l|r|r|r|r|}
\hline & \multicolumn{1}{|c|}{ Average } & Std. Deviation & \multicolumn{1}{c|}{ Minimum } & \multicolumn{1}{c|}{ Maximum } \\
\hline SBLRATIO & 0.0167 & 0.0100 & 0.0015 & 0.0510 \\
\hline LNASSETS & 9.3859 & 1.2660 & 7.2364 & 12.3351 \\
\hline BANKS & 6.9053 & 8.6234 & 1.0000 & 38.0000 \\
\hline BRANCHES & 367.3789 & 476.5632 & 13.0000 & 2617.0000 \\
\hline HHI & 0.1880 & 0.0602 & 0.0709 & 0.5005 \\
\hline SANFRAN & 0.1263 & 0.3340 & 0.0000 & 1.0000 \\
\hline NEWYORK & 0.0737 & 0.2626 & 0.0000 & 1.0000 \\
\hline ADVDEG & 0.4737 & 0.5020 & 0.0000 & 1.0000 \\
\hline CEOTEN & 9.1789 & 7.8753 & 0.0000 & 40.0000 \\
\hline ROE & 0.1588 & 0.3291 & 0.0728 & 0.2526 \\
\hline NIINCOME & 0.2984 & 0.0997 & 0.0951 & 0.6405 \\
\hline
\end{tabular}


Table 2

Simple Correlation Coefficients

\begin{tabular}{|c|c|c|c|c|c|c|c|c|c|c|c|c|c|}
\hline & ADOPT & YEARS & SBLRATIO & LNASSETS & BANKS & BRANCHES & $\mathrm{HHI}$ & SF & NY & ADVDEG & CEOTN & $\mathrm{ROE}$ & NIINC \\
\hline ADOPT & 1.00 & & & & & & & & & & & & \\
\hline YEARS & $0.75^{* * * *}$ & 1.00 & & & & & & & & & & & \\
\hline SBLRATIO & $-0.22^{* * *}$ & -0.16 & 1.00 & & & & & & & & & & \\
\hline LNASSETS & $0.46^{* * * *}$ & $0.51^{* * * *}$ & $-0.46^{\text {***** }}$ & 1.00 & & & & & & & & & \\
\hline BANKS & -0.05 & -0.07 & 0.04 & $0.27^{* * * *}$ & 1.00 & & & & & & & & \\
\hline BRANCHES & $0.38^{* * * *}$ & $0.50^{* * * * *}$ & $-0.25^{* *}$ & $0.80^{\text {***** }}$ & $0.34^{* * * *}$ & 1.00 & & & & & & & \\
\hline HHI & -0.13 & -0.10 & $0.40^{* * * *}$ & $-0.21^{* *}$ & -0.06 & -0.09 & 1.00 & & & & & & \\
\hline $\mathrm{SF}$ & 0.07 & -0.01 & -0.03 & 0.09 & -0.06 & 0.14 & 0.10 & 1.00 & & & & & \\
\hline NY & 0.16 & $0.19^{*}$ & $-0.21^{* * *}$ & 0.12 & -0.14 & -0.03 & -0.03 & -0.11 & 1.00 & & & & \\
\hline ADVDEG & 0.17 & $0.25^{* * *}$ & -0.08 & $0.35^{* * * *}$ & 0.10 & $0.22^{* *}$ & -0.02 & -0.04 & -0.03 & 1.00 & & & \\
\hline CEOTN & -0.13 & -0.06 & $0.22^{* *}$ & -0.16 & 0.13 & -0.07 & 0.10 & -0.03 & 0.03 & -0.07 & 1.00 & & \\
\hline ROE & -0.7 & -0.12 & -0.12 & 0.02 & 0.09 & -0.13 & -0.09 & -0.14 & $0.21^{* * *}$ & $0.18^{*}$ & -0.13 & 1.00 & \\
\hline NIINC & 0.07 & 0.13 & $-0.19^{*}$ & $0.18^{*}$ & $0.18^{*}$ & $0.28^{* * * *}$ & -0.04 & -0.08 & -0.13 & $0.25^{* * *}$ & -0.12 & 0.14 & 1.00 \\
\hline
\end{tabular}

* Statistically significant at the $10 \%$ level.

** Statistically significant at the 5\% level.

*** Statistically significant at the $1 \%$ level. 
Table 3

Hazard Model Estimates of the Length of Time to Adoption

Of Small Business Credit Scoring

Dependent Variable: $\ln (\mathrm{TIME})$

\begin{tabular}{|l|r|r|r|}
\hline & Coefficient & T-Statistic & Probability \\
\hline Constant & $3.1627 * * *$ & 3.320 & 0.0009 \\
\hline SBLRATIO & 3.0062 & 0.376 & 0.7068 \\
\hline LNASSETS & $-0.1968^{*}$ & -1.874 & 0.0609 \\
\hline BANKS & 0.0022 & 0.361 & 0.7179 \\
\hline BRANCHES & -0.0002 & -0.742 & 0.4580 \\
\hline HHI & 0.0006 & 0.001 & 0.9996 \\
\hline SANFRAN & 0.0702 & 0.326 & 0.7445 \\
\hline NEWYORK & $-0.3654 *$ & -1.703 & 0.0886 \\
\hline ADVDEG & -0.0004 & -0.003 & 0.9973 \\
\hline CEOTEN & -0.0026 & -0.287 & 0.7744 \\
\hline ROE & 0.2848 & 0.186 & 0.8523 \\
\hline NIINCOME & 1.0012 & 1.323 & 0.1858 \\
\hline & & & \\
\hline$\lambda=\exp \left(-\beta{ }^{\prime} \mathrm{X}\right)$ & 0.1940 & & \\
\hline P $1 / \sigma$ & 2.6657 & & \\
\hline Median & 4.4923 & & \\
\hline
\end{tabular}

Log-likelihood $=-136.0775 ;$ chi-square $=35.0242$

* Statistically significant at the 10 percent level.

** Statistically significant at the 5 percent level.

*** Statistically significant at the 1 percent level. 
Table 4

Tobit Estimates of Variables Influencing the Rate of Adopting

Small Business Credit Scoring

Dependent Variable: YEARS

(June 30, 1997 Data)

\begin{tabular}{|l|r|r|r|}
\hline & \multicolumn{1}{|c|}{ Coefficient } & \multicolumn{1}{|c|}{ T-Statistic } & \multicolumn{1}{c|}{ Probability } \\
\hline Constant & -4.3946 & -1.533 & 0.1252 \\
\hline SBLRATIO & 26.9891 & 1.123 & 0.2616 \\
\hline LNASSETS & $0.7268 * *$ & 2.419 & 0.0156 \\
\hline BANKS & $-0.0639 * * *$ & -2.663 & 0.0077 \\
\hline BRANCHES & 0.0010 & 1.497 & 0.1343 \\
\hline HHI & -3.3464 & -0.916 & 0.3595 \\
\hline SANFRAN & -0.4576 & -0.814 & 0.4155 \\
\hline NEWYORK & 1.1691 & 1.625 & 0.1042 \\
\hline ADVDEG & 0.5378 & 1.393 & 0.1636 \\
\hline CEOTEN & -0.0075 & -0.298 & 0.7657 \\
\hline ROE & -8.0597 & -1.312 & 0.1895 \\
\hline NIINCOME & -1.6310 & -0.751 & 0.4527 \\
\hline
\end{tabular}

Log likelihood $=-151.8044 ;$ chi-square $=46.1456$

* Statistically significant at the 10 percent level.

** Statistically significant at the 5 percent level.

*** Statistically significant at the 1 percent level. 